\title{
KRÓL WĘGIERSKI ANDRZEJ II NA TRONIE W CESARSTWIE ŁACIŃSKIM? BAŁKAŃSKI WĄTEK V KRUCJATY
}

\author{
ZDZISŁAW PENTEK
}

\begin{abstract}
Hungarian King Andrew II on the throne in the Latin Empire? The Balkan thread of the Fifth Crusade.

The article focuses on the participation of the Hungarian King Andrew II in the Fifth Crusade in 1217. The author rejects the speculations (B. Hóman, S. Runciman, F. Van Tricht et al.) that the reason of the king's decision was ascending the throne of the Latin Empire after the death of the emperor Henry in 1216. Due to the lack of evidence in sources for these speculations, the author claims that the reasons for which Andrew II took part in the Fifth Crusade were rather prestigious, devotional and ambition oriented.
\end{abstract}

STRESZCZENIE. Artykuł jest poświęcony przyczynom udziłu króla Węgier Andrzeja II w V krucjacie w 1217 roku. Autor odrzuca przypuszczenia (B. Hóman, S. Runciman, F. Van Tricht i in.) jakoby u podstaw decyzji monarchy legło objęcie tronu w Cesarstwie Lacińskim pod śmierci cesarza Henryka w 1216 roku. Wobec braku umocowania źródłowego takich hipotez, autor wśród powodów, dla których Andrzej II wziął udział w V krucjacie widzi szereg przyczyn innej natury, np. kwestii prestiżowych, dewocyjnych i ambicjonalnych.

Autor: Zdzisław Pentek, Uniwersytet im. Adama Mickiewicza w Poznaniu, Instytut Historii, ul. Umultowska 89d, 61-614 Poznań, Polska, e-mail: zp26@amu.edu.pl

Keywords: Balkans, Hungary, Andrew II, Byzantium, V crusade

Słowa kluczowe: Bałkany, Węgry, Andrzej II, Bizancjum, V krucjata

Balcanica Posnaniensia. Acta et studia, XXIV, Poznań 2017, Wydawnictwo Instytutu Historii UAM, pp. 17-29, ISBN 978-83-65663-50-4, ISSN 0239-4278. Polish text with summaries in English and Polish.

doi.org/10.14746/bp.2017.24.2

IV krucjata nie przyniosła spodziewanych rezultatów, w ogóle nie docierając do Ziemi Świętej. Jej inicjator, papież Innocenty III (1198-1216) być może już od 1207 roku pragnął zorganizować nową wyprawę krzyżową, która powstrzymywałaby rozrost domeny muzułmańskiej na Wschodzie. Powodów, aby podjąć nową wyprawę było kilka: osłabienie wrażenia blamażu po zajęciu Konstantynopola przez IV krucjatę, chęć wzmocnienia jedności Kościoła, porażka andaluzyjskich muzułmanów pod Las Navas de Tolosa 16 VII 1212 roku (co mogło dawać tylko optymistom nadzieję, że podobnego niepowodzenia doświadczą innowiercy w Palestynie), oraz zlikwido- 
wanie niesmaku po krucjacie dziecięcej z 1212 roku$^{1}$. Niezniechęcony swoim pierwszym krucjatowym przedsięwzięciem, Innocenty III, w bulli Vineam Domini Sabaoth z 19 IV 1213 roku zapowiadał zwołanie wielkiego soboru powszechnego do Rzymu. Odbył się on w bazylice laterańskiej w listopadzie 1215 roku. Obrady dotyczyły ważnych kwestii z punktu widzenia Kościoła, czego dowodem było zatwierdzenie przez IV Sobór Laterański 71. kanonów. W ostatnim z nich, co dość wymowne, uczestnicy Soboru apelowali o nową krucjatę. A zatem papiestwo zdawało sobie sprawę, że idea krucjatowa przeżywała się i schodziła na margines polityki Kościoła. Początek krucjaty wyznaczono na 1 VI 1217 roku. Na czele wyprawy miał stanąć Fryderyk II Hohenstauf, pod czujnym okiem legata papieskiego. Uczestnicy wyprawy mieli pożeglować z Brindisi lub Mesyny do Ziemi Świętej. ${ }^{2}$ Innocenty III zainicjował kolejną krucjatę podczas swego pontyfikatu, jednak nie doczekał się jej początku, zmarł bowiem, 16 lipca 1216 w Perugii.

Jest to okazja do napisania kilku słów w związku z przypadającą w 2017 roku, 800. rocznicą $\mathrm{V}$ wyprawy krzyżowej. Zamierzam się skupić na jej dość peryferyjnym, bałkańskim wątku, i odnieść się do kwestii niektórych motywów, które sprawiły, że na krucjatę wyruszył król Węgier Andrzej II (1205-1235). Jednym z takich motywów, który raz po raz podnoszony jest w literaturze historycznej, miały być jego nadzieje na tron Cesarstwa Łacińskiego w Konstantynopolu.

O przebiegu tej wyprawy w zasadzie wszystko, albo prawie wszystko już napisano, co dało się wydobyć ze źródeł dokumentalnych i narracyjnych. Wyczerpujący materiał zebrał w końcu XIX w. niemiecki profesor gimnazjalny, Reinhold Röhricht (1842-1905). ${ }^{3}$ Uczynił to tak skrupulatnie, że nie ma już co dorzucić. Plon jego działań na tym polu jest rozległy, bo obok tych zebranych źródeł, napisał nadal w literaturze ważną monografię V krucjaty. ${ }^{4}$ Po Röhrichtcie działały kolejne zastępy badaczy i w sposób zasadny czuły się zwolnione z ponownych, mozolnych badań źródłoznawczych. Przyszła, więc pora na rozmaite domysły i hipotezy, słowem na refleksje, które pobudzają do budowania różnych teorii.

W 1943 roku Bálint Hóman (1885-1951), w drugim tomie Geschichte des ungarischen Mittelalters, jeden z swoich podrozdziałów wymownie zatytułował Ver-

${ }^{1}$ Zamysł nowej krucjaty zrodził się być może już w 1207 roku, kiedy wrócił do Rzymu z Cesarstwa Łacińskiego kardynał Benedykt z Saint-Suzaine, który był legatem papieskim i przedstawił mizerię panującą w tym państwie, tak sądził Thomas Curtis van Cleve (1888-1976) w: The history of the crusades, ed. by Kenneth M. Setton, vol. II, Madison, Milwuakee, London 1969, s. 378, 386-388; Chronica Albrici monachii Trium Fontium a monacho novi monasterii Hojensis interpolata, ed. Paul SchefferBoichorst, MGH SS 23, s. 905.

${ }^{2}$ Dokumenty soborów powszechnych, tekst grecki, laciński, polski, tom II (869-1312). Konstantynopol IV, Lateran I, Lateran II, Lateran III, Lateran IV, Lyon I, Lyon II, Vienne, układ i opracowanie ks. Arkadiusz Baron, ks. Henryk Pietras SJ, Kraków 2002, s. 314-325: Ac liberandam Terram sanctam de manibus impiorum, ardenti desiderario adspirantes...; zob. też J. Hauziński, Imperator "końca świata" (1194-1250), Gdańsk 2000, s. 45-46, 48.

${ }^{3}$ R. Röhricht, Quinti Belli sacri scriptores minores, Genf 1879; R. Röhricht, Testimonia minora de quinto bello sacro e chronicis occidentalibus, Genf 1882

${ }^{4}$ R. Röhricht, Studien zur Geschichte des fünften Kreuzzuges, Innsbruck 1891, zwłaszcza s. 3-36. 
suche zur Erringung des Kaiserthrons von Byzanz, odnosząc te słowa do zamiarów Andrzeja II. ${ }^{5}$ W strzemięźliwość okazał Jean Longnon w 1949 roku w L'Empire Latin de Constantinople et la Principauté de Morée, oceniając, że wybór króla węgierskiego mógł być bardziej przydatny dla Cesarstwa, jednak nie wspominał o żadnej grupie popierającej tę kandydaturę. ${ }^{6}$ Zdaje się, że następną hipotezę - nie wiedząc o pracy B. Hómana - ogłosił w latach 50. XX wieku, niewątpliwy autorytet badań nad krucjatami, Sir Steven Runciman (1903-2001), piszac w III tomie A History of the Crusades:

King Andrew II of Hungary had already taken the cross, but had been excused by Innocent from fulfil-
ling his vow earlier becuase of civil war in his country. He now showed zeal, but he had another mo-
tive. His queen was the niece, through her mother, of Latin Emperor Henry of Constantinople, who
was childless, and he had hopes of the inheritance. But when Henry died in June 1216, her father,
Peter of Courtenay, was chosen in his place. King Andrew's ardour began to fade; but he agrees at
last to have his army ready by the following summer.

To rzecz jasna interpretacja, ale wyszła ona spod pióra S. Runcimana i ma swój ciężar gatunkowy, mogąc wywierać wpływ na późniejsze sądy historiografii. Z tego tekstu wynika, że król Węgier liczył na objęcie tronu w Konstantynopolu od momentu poślubienia Jolanty - tu Runciman nie podał żadnej daty - do czerwca 1216 roku, kiedy to wybór padł na Piotra z Courtenay. Warto przypatrzyć się dokładniej, czy B. Hóman i S. Runciman mieli rację snując takie przypuszczenia. A także wtórujący im, zwłaszcza B. Hómanowi, historyk-bizantynista Ferenc Makk (*1940) i historyk, znawca średniowiecznych dziejów węgierskich, Gyula Kristó (1939-2004). ${ }^{8}$

${ }^{5}$ B. Hóman, Geschichte des ungarischen Mittelalters, 2. Band: Vom Ende des 12. Vom Ende des 12. Jahrhuderts bis zu den Anfängen des Hauses Anjou, Übersetzung Hildegard von Roosz und Max Pfotenhauer, Berlin 1943, s. 14. Autor nie powołuje się na żadne źródło, brak też aparatu komentarzowego w całej książce. Nie można zapominać, że B. Hómana zaliczono w poczet historyków o poglądach nacjonalistycznych, co rzecz jasna, nie musi czegokolwiek przesądzać.

6 J. Longnon, L'Empire Latin de Constantinople et la Principauté de Morée, Paris 1949, s. 153.

${ }^{7}$ Runciman, A History of the Crusades. Volume III. The Kingdom of Acre and the later Crusades, Cambridge 1955, s. 146 lub wydanie polskie Dzieje wypraw krzyżowych, thum. Jerzy Schwakopf, t. 3, Warszawa 1987, s. 147-148: „Już wcześniej wziął krzyż król Andrzej II węgierski, ale Innocenty zwolnił go od ślubu, ponieważ w jego państwie wybuchła wojna domowa. Obecnie zapragnął gorąco wziąć udział w krucjacie, ale już z innych powodów. Jego żona Jolanta była siostrzenicą cesarza łacińskiego Henryka, a ponieważ Henryk nie miał dzieci, król Andrzej liczył na odziedziczenie po nim tronu konstantynopolitańskiego. Jednakże po śmierci Henryka w czerwcu 1216 na cesarza wybrano ojca królowej Jolanty, Piotra z Courtenay. Zapał króla Andrzeja zaczął przeto przygasać, niemniej obiecał przysposobić oddziały węgierskie najpóźniej do lata następnego roku."

${ }^{8}$ List Innocentego III, XV, 224, Migne, Patrologia Latina, vol. 216, col. 757; Vetera Monumenta historica Hungariam sacram illustrantia, I, ed. Augustino Theiner, Romae 1859, s. 5-6. S.; Z. Pentek, Cesarstwo Łacińskie 1204-1261. Kolonialne państwo krzyżowców czy Neobizancjum? Poznań 2004, s. 144, znacznie ostrożniej i bez dalszych teoretycznych założeń: Nie jest wykluczone, że Andrzej II zdawat sobie sprawe, że Henryk jest bezpotomny i przy szczęśliwym dla siebie rozwoju wypadków [...] mógt liczyć na koronę w Konstantynopolu; żadnej hipotezy nie postawił R. Grousset, Historie des croisades et du Royaume Franc de Jérusalem, t. 3, Paris 1936, s. 200n; T. Almási, II. András w: Noémi Gujdár, Nóra 
Najpierw wydarzenia z lat 1214-1216 spróbuję zrekonstruować z punktu widzenia Konstantynopola. Obraz ten jest obarczony poważnymi niedostatkami źródłowymi, co jest dość krępujące, ale za to daje szeroką przestrzeń do interpretacji. Cesarz łaciński, Henryk (1206-1216), następca swego brata Baldwina I (1204-1206), zdecydował - najprawdopodobniej w 1214 roku - o kampanii wojennej przeciwko wielkiemu żupanowi Serbii, Stefanowi II Nemaniczowi (1196-1228). Poza przypuszczeniami, niezbyt jasne są powody zorganizowania tej wojny przez Henryka. Z inicjatywy Henryka korzystał ówczesny sojusznik Łacinników, czyli II Państwo Bułgarskie pod rządami cara Boriła (1207-1217). Władca bułgarski został zmuszony do zawarcia pokoju z Henrykiem oraz zgody na ślub (pomiędzy 5 VIII 1213 a 4 VIII 1214) swej pasierbicy Marii z cesarzem. ${ }^{9}$ Borił zainicjował walki ze Stefanem II, do czego włączył się również swego brata Streza (1207-1214). ${ }^{10}$ Żołnierze bułgarsko-łacińskiego wojska dotarli zwycięsko do serbskiego Niszu. Tam, być może, wiosną 1215 roku, cesarz łaciński Henryk zawarł porozumienie z królem Andrzejem II przeciwko Serbom, przy okazji pozbawiając pewnych terytoriów ich dotychczasowego władcę, Stefana II. ${ }^{11}$ Ale sojusz pomiędzy cesarzem i królem okazał się bardzo nietrwały. Kiedy Henryk powracał z Niszu do Konstantynopola, to Andrzej II nieoczekiwanie zmienił swe sympatie polityczne i zawarł porozumienie ze Stefanem II, tym samym powracając do wcześniejszego sojuszu Węgier i Serbii. Andrzej II zagwarantował stabilne granice węgiersko-serbskie i odwołał homagium przed cesarzem łacińskim. W odwecie za te działania Andrzeja II, cesarz wszczął drugą kampanię wojenną w 1215 roku. Walki rozpoczął Borił. Zanim Henryk zebrał siły, aby wspomóc cara, koalicja Andrzeja II i Stefana II rozprawiła się z Boriłem. Akcje zbrojne Henryka przeciwko Stefanowi II w 1215 roku zakończyły się porażką cesarza i zerwaniem dobrych kontaktów dotychczasowym sojusznikiem, z Węgrami. ${ }^{12}$ Wiosną roku 1216, zapewne w maju, Henryk

Szatmáry, Magyar királyok nagykönyve. Uralkodóink, kormányzóink és az erdélyi fejedmek életének és tetteinek képes töténete, Budapest 2012, s. 85-87, akceptuje wymowę hipotez B. Hómana i S. Runcimana. Domysł, że Runciman nie znał książki B. Hómana wysuwam z tego, że Brytyjczyk nie podaje jej w swoim zestawieniu bibliograficznym.

9 J. Longnon, L'Empire Latin de Constantinople et la Principauté de Morée, Paris 1949, s. 149; Z. Pentek, Cesarstwo Lacińskie 1204-1261. Kolonialne państwo krzyżowców czy Neobizancjum? Poznań 2004, s. 141-142, a także p. 101.

${ }^{10}$ J. M. Wolski, „Żywot św. Sawy” Teodozjusza Chilandarskiego, jako źródto do dziejów Streza, władcy Proseku, „Balcanica Posnaniensia. Acta et studia” XIX [2012], s. 51-69, thumaczenie tekstu źródłowego na s. 62-68.

${ }^{11}$ Wydaje się to potwierdzać niedatowany dokument - B. Hendrickx, Régestes des empereurs la-

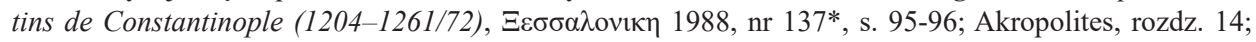
Codex dipomaticus Regni Croatiae, Dalmatiae et Slavoniae, collegit et digessit T. Smičiklas, Zagrebiae 1904, vol. III, 318; К. Јиречек, Историја Срба, t. 1, Београд 1952, s. 167-168; T. Wasilewski, Stefan Nemanjić, SSS 5, s. 1415-1416.

12 И. Божилов, Фамилята на Асеневци (1186-1460). Генеалогия и просопография, София 1985, s. 98-100; Z. Pentek, Cesarstwo, s. 143; J. M. Wolski, „Żywot św. Sawy”..., s. 58-61; odmiennie uważa F. Van Tricht, The Latin Renovatio of Byzantium. The Empire of Constantinople (1204-1228), translated by Peter Longbottom, Leiden-Boston 2011, s. 414n, podaje, że stosunki łacińsko-węgierskie nie uległy pogorszeniu. Autora nie dziwi fakt, że Andrzej II udał się do Ziemi Świętej drogą morską. Gdyby sto- 
wyruszył, jak się potem okazało, w swą ostatnią podróż. Jej cel - Saloniki i powody wyjazdu właśnie tam, pozostaną dla nas nieznane, choć można przypuszczać, że chodziło o koronację Dymitra, syna salonickiego władcy, Bonifacego z Montferrat (zm. 1207). Cesarz łaciński niespodziewanie zmarł 11 VI 1216 roku w Salonikach. Nic nie wiadomo, czy istniał jakiś testament polityczny zmarłego cesarza, jakaś inna wskazówka odnośnie ewentualnego następcy.

Zatem na barki baronów Cesarstwa, a zwłaszcza jego żyjących współzałożycieli, spadł ciężar podjęcia kroków dotyczących sukcesji po zmarłym cesarzu. W czerwcu lub lipcu 1216 roku baronowie Cesarstwa podjęli kluczowe decyzje odnośne następstwa tronu w Konstantynopolu. Kulis tych narad nie oświetlają nam żadne źródła, co raczej nie może dziwić. Wynik narad był jednoznaczny, cesarskie berło miało pozostać w obrębie rodziny zmarłych braci - Baldwina i Henryka. ${ }^{13}$ Ich siostrą była Jolanta Flandryjska (1175-1219) zaślubiona Piotrowi z Courtenay (zm. 1217). ${ }^{14}$ To jemu zaoferowano tron, na którym miał on zasiąść po przybyciu do Konstantynopola. W zachowanych dokumentach i przekazach narracyjnych nie ma słowa o innych kandydatach. Zatem należy przyjmować wręcz za pewnik, że nie brano pod uwagę córki z Piotra z Courtenay i Jolanty Flandryjskiej, również Jolanty, żony Andrzeja II. Zdawano sobie sprawę, że Jolanta i jej małżonek, nie są pierwszymi w kolejności do tronu w Konstantynopolu. Andrzej II nie był też Frankiem i prawdopodobnie wzięto to pod uwagę, jeśli w ogóle rozpatrywano jego kandydaturę.

Jak wówczas ogólnie wyglądała sytuacja Węgier i jego władcy, Andrzeja II? Rzekome związki Węgier z krucjatami otwiera postać Władysława I Świętego (10771095). Miał on zostać, według autora Chronica de Gestis Hungarorum, wodzem I krucjaty, ale zmarł 29 VII 1095 r., jeszcze przed wezwaniem Urbana II. Prowadzenie krucjaty przez Władysława I było projekcją wydarzeń, spisaną w drugiej połowie XIV wieku przez kanonika Marka z Kaltu (węg. Kálti Márk). Zdaje się, że chodziło o dodatkowy laur do świętości węgierskiego króla, i tak kanonizowanego już 1192 roku. Może istniała jakaś tradycja krucjatowa w rodzinie Arpadów, związana z zamiarami Władysława I, ale tego nie da się potwierdzić. Należy także odwołać się do tego, co jest dowodne, czyli do czasów powiększania się domeny węgierskiej na

sunki z Bułgarią i Cesarstwem Łacińskim były poprawne, to trasa przemarszu mogła wyglądać odmiennie, zob. I. Czamańska, Aspekty ruchu krucjatowego na Węrzech w XI-XV wieku w: Rycerstwo Europy środkowo-Wschodniej wobec idei krucjat. Redakcja naukowa Wojciech Peltz, Jarosław Dudek, Zielona Góra 2002, s. 132.

${ }^{13}$ Odmiennego zdania był Fiodor Uspienskij, twierdząc, że byli jacyś zwolennicy wyboru Andrzeja II, ale autor nie podał źródła swych wiadomości - Ф. И. Успенский, История Византийской Империи, Москва-Ленинград 1948, s. 474, 476. Chyba, nieświadomy słów F. Uspienskiego był J. Longnon, zob. p. 6.

${ }^{14}$ Urkunden zur älteren Handels- und Staatsgeschichte der Republik Venedig mit besonderer Beziehung auf Byzanz und die Levante, ed. G. L. Tafel, G. M. Thomas, Wien 1856, w: Fontes rerum Austriacarum, Österreichische Geschichts-Quellen, hrsg. von der Historischen Commission der Kaiserlichen Akademie der Wissenschaften in Wien. Zweite Abteilung: Diplomataria et acta, Bde. II, s. 193-195;

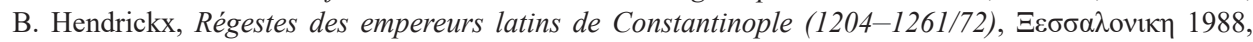
nr 138, s. 96-97 ; Z. Pentek, Cesarstwo..., s. 195. 
Bałkanach, jeszcze na przełomie XI i XII wieku, gdyż wytwarzało to nową jakość geopolityczną w tej części Europy. W 1094 roku Władysław I przyłączył do Węgier Slawonię. Jego następca Koloman I (1096-1116) po raz pierwszy wyprawił się wiosną 1097 roku na Chorwację, w wyniku czego król Piotr poległ, ale to jeszcze nie złamało oporu Chorwatów. Wojska węgierskie wycofały się wówczas z Chorwacji. Koloman I w 1102 roku jeszcze raz zwrócił swoją militarną potęgę przeciw Chorwacji, którą uwieńczył koronacją w Biogradzie. Chorwacja jako niezależne państwo przestała istnieć wiążąc się $\mathrm{w}$ unię personalną z Węgrami. Następnym ogniwem w podbojach Bałkan przez Węgry był Stefan II (1116-1131), który zajął w 1127 roku Belgrad, Nisz oraz Sofię. Jego następca, Béla II Ślepy (1131-1141), w 1137 roku wkroczył do północnozachodniej Bośni i rozpoczął się tytułować się władcą Węgier, Chorwacji i królem Bośni. Jego zaś syn, niedoszły krzyżowiec II krucjaty, Géza II (1141-1162), wprawdzie na początku swego panowania władał jeszcze rozległymi ziemiami, to wkrótce po tej krucjacie, sytuacja zaczęła zmieniać się na jego niekorzyść.

Młody cesarz bizantyński, Manuel I (1143-1180), około 1150 roku rozpoczął prowadzić walki o utracone terytoria na Morzu Adriatyckim (wyspa Korfu) i Półwyspie Bałkańskim. Jego ofensywa, z lat $1150-1152$, przyniosła mu podporządkowanie Zety. ${ }^{15}$ Cesarzowi również zależało na uzależnieniu Węgier i dlatego wykorzystał spory dynastyczne wśród Arpadów po śmierci Gézy II. Z walk o tron węgierski, zwycięsko wyszedł Stefan III (1162-1172), ale stało się to kosztem osłabienia państwa, a brata Bélę, król był zmuszony wysłać, jako zakładnika, do Konstantynopola.

Węgierski książę Béla przybył do stolicy Imperium w 1163 roku. Wówczas otrzy-

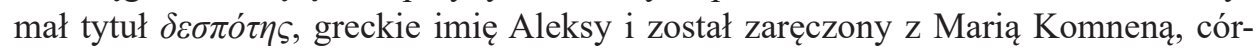
ką Manuela I. ${ }^{16}$ Wszystko to nie działo się bez przyczyny. Matką cesarza Manuela I była węgierska księżniczka Piroska [Pryska] (ok. 1088-1134), która na dworze greckim przyjęła nowe imię, Irena. Była ona córką Władysława I Świętego. To odwołanie do genealogicznych powiązań jest tu niezbędne, aby zrozumieć, dlaczego pomysł Manuela I był uzasadniony, aby Béla mógł pretendować do tronu bizantyńskiego. Był on dowodnie spokrewniony z imperatorem i wobec tego, mógł być brany pod rozwagę w latach 1163-1169 jako ewentualny następca tronu w Bizancjum, wszak po jednym warunkiem, że Manuel I nie doczekałby się męskiego potomka. To mogło być początkiem węgierskiej wątłej nadziei na tron w Konstantynopolu, ale i wizji bizantyńskiej, na włączenie do swego państwa Arpadów.

${ }^{15}$ Chronica de Gestis Hungarorum ab origine gentis ad a. 1330, ed. Dezső Dercsény, New Tork 1970, roz. 100. 139, s. 130; F. Makk, The Árpáds and the Comneni: Political relations between Hungary and Byzantium in the 12 the century, trans. by György Novák, Budapest 1989, s. 58 [dalej: Makk 1989].

${ }^{16}$ Wiemy o tym od Kinnamosa - Ioannis Cinnami, Epitome, rerum ab Ioanne et Alexio Comnenis gestarum, ed. Augustus Meineke, Bonnae 1836, s. 214, 23; 222, 17; 236, 22 [dalej Kinnamos]; G. Moravcsik, Pour une alliance byzantino-hongroise, „Byzantinische Zeitschrift” 33 [1933], s. 556-557; G. Ostrogorsky, Urum-Despotes. Die Anfänge der Despoten würde in Byzanz, „Byzantinische Zeitschrift” 44 [1951], s. 448-450; F. Sišić, Poviest Hrvata za kraljeva iz doma Arpadovića, Zagreb 1944, s. 88-87; Makk 1989, s. 58; S. A. Sroka, Historia Węgier do 1526 roku w zarysie, Bydgoszcz 2000, s. 32-34. 
W 1167 roku, król Stefan III odmówił Bizantyńczykom przekazania dochodów z domeny Béli przebywającego w Królowej Miast. Była to przyczyna krótkiej wojny bizantyńsko-węgierskiej, rozstrzygniętej na korzyść Manuela I, jeszcze w lipcu 1167 roku pod Sirmium (ob. serbska Sremska Mitrovica). ${ }^{17}$ Skutki tej porażki dla Węgier były dotkliwe, choć krótkotrwałe. Węgry stały się zależne politycznie od Bizancjum, a Kościół węgierski miał się znaleźć w gestii patriarchy Konstantynopola. Jednak 10 IX 1169 roku narodził się syn cesarza, późniejszy Aleksy II (1180-1183), co było bezpośrednią przyczyną zerwania zaręczyn Béli z Marią Komneną. Być może cesarz chciał zatrzeć niesmak z powodu niedoszłego matrymonium, ale i pozostawić Bélę w kręgu rodzinnym oraz ewentualnych następców, gdyby młody Aleksy nagle zmarł. W związku z tym, basileus zainicjował ożenek Béli z Agnieszką z Châtillon (1154-1184) (na Węgrzech używała imienia Anna), przyrodnią siostrą swej żony, Marii z Antiochii (1145-1182). ${ }^{18}$ Wprawdzie Béla nie został cesarzem, ale jego szwagrem był Manuel I.

Po śmierci królowej Agnieszki-Anny, Béla III (1172-1196) - już jako król Węgier - być może marząc o niespełnionych nadziejach władania Bizancjum, w 1185 roku bezskutecznie zabiegał o zgodę na ślub z, nieznaną z imienia, córką Marii[?] i Jana Angelosa, a wnuczką siostry Manuela I, Teodory Komneny (1115-ok. 1157), wdową po Manuelu Anemasie. ${ }^{19}$ Ta jednak, już zamknęła za sobą bramy klasztoru, a Kościół grecki był niechętny do zwolnienia jej ze ślubów zakonnych. Wobec tego, Béla III w 1186 roku poślubił siostrę francuskiego monarchy Filipa II Augusta (1180-1223), Małgorzatę (1157-1197), tym samym zacieśniając kontakty pomiędzy Węgrami a Francją.

Béla III wykorzystując polityczne zmiany i niepokoje w Bizancjum po śmierci Manuela I, odniósł dostrzegalne sukcesy terytorialne, zajmując zrazu Slawonię. Wraz z wielkim żupanem Raszki Stefanem Nemaniczem (1170-1196), zajęli oni jeszcze Belgrad i Nisz. Jednak nadzieja Béli III na tron w Bizancjum po śmierci Manuela I była mrzonką. Po śmierci Béli III w 1196 roku tron wszedł w posiadanie Emeryka I (1196-1204). W czasie trwającej rywalizacji o tron węgierski pomiędzy Emerykiem I i Andrzejem, Węgrzy utracili w listopadzie 1202 roku Zadar na rzecz Wenecjan i krzyżowców IV krucjaty, rzekomo podążających do Ziemi Świętej. To niewątpliwie

17 Kinnamos, s. 223-231, 6; Makk 1989, s. 89-90.

18 F. Dölger, Regesten der Kaiserkunden des oströmischen Reiches von 565-1453, Bd. II, München 1959, nr 1455; R. Browning, A new source in Byzantine-Hungarian relations in the twelfth century, „Balkan Studies" 2 (1961), s. 173-214, zwłaszcza s. 180n; G. Ostrogorsky, Dzieje Bizancjum. Przekład pod redakcją H. Evert-Kappesowej, Warszawa 1969, s. 312; G. Moravcsik, Byzantium and the Magyars, BudapestAmsterdam 1970; Makk 1989, s. 106, 119; G. Kristó, F. Makk, Az Arpád-ház uralkodói, Budapest 1996, s. 209n; P. Stephenson, Byzantium's Balkan Frontier. A political study of the Northern Balkans, 900-1204, Cambridge 2000, s. 283; P. Magdalino, The Empire of Manuel I Komnens 1143-1180, Cambridge 1993; S. A. Sroka, Historia Węgier do 1526 roku w zarysie, Bydgoszcz 2000, s. 35-40.

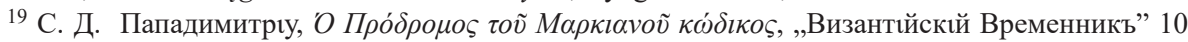
[1903], s. 111, za nim L. Stiernon, Notes de titulature et de prosopographiè, „Revue des Études Byzantines”

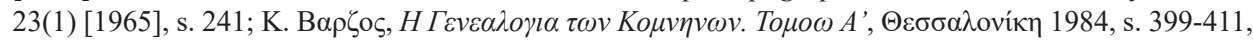
tabl. geneal. oraz To $\mu о \omega$ B', s. 364-368. 
zaszkodziło relacjom węgiersko-weneckim w następnych latach. Po śmierci Emeryka I na krótko władzę przejął jego syn Władysław (1204-1205), a po nim tron przypadł Andrzejowi II.

Od momentu rozpoczęcia rządów Andrzeja II rozpoczął on wieloletnie i niełatwe próby zdławienia niezadowolenia części węgierskich magnatów niechętnych jego panowaniu. Wynikało to $\mathrm{m}$. in. z faktu, że pierwszą małżonką króla była powszechnie znienawidzona Gertruda z Meran (1185-1213) transmitująca niemiecką politykę, przede wszystkim z bratem Bertholdem (1180-1251), arcybiskupem Kalocsa (12061218). Następstwem tej rywalizacji Andrzeja II z możnymi było zamordowanie królowej w lesie Pilis, we wrześniu 1213 roku. Co ciekawe, była ona siostrą królowej Francji, Agnieszki (ok. 1172-1201), trzeciej żony Filipa II Augusta. Również Andrzej II poszedł tropem swego ojca, Béli III, który poślubił siostrę Filipa II Augusta, mając za szwagra tego krzyżowca III krucjaty. Po okresie żałoby, Andrzej II, poślubił w lutym 1215 roku Jolantę (ok. 1200-1233), córkę Piotra z Courtenay (zm. ok. 1217), hrabiego Namur oraz Jolanty Flandryjskiej (zm. 1219). Te genealogiczne rozważania są ponownie dość istotne. Ukazują one drogi osiągania pozycji dynastycznej władców węgierskich w końcu i początku XIII wieku. Król Andrzej tym samym stawał się nie tylko powinowatym Filipa II Augusta, ale przede wszystkim, cesarza łacińskiego Henryka.

Zaślubiny Andrzeja II z młodą Jolantą wpłynęły na przejściowe ocieplenie stosunków pomiędzy Węgrami a Cesarstwem Łacińskim, ale nic bliższego o tym nie wiadomo. Ale czy to automatycznie dawało Andrzejowi II szansę na tron w Konstantynopolu, o czym nadmieniał S. Runciman i inni? Węgierski monarcha, jeśli w ogóle liczył na schedę po Henryku (obaj byli prawie równolatkami, pierwszy urodził się w 1176, drugi zaś w 1174), to mógł tak hipotetycznie czynić tylko od lutego 1215 roku (ożenek z Jolantą) do chwili zawarcia układu ze Stefanem II, czyli do wiosny lub lata 1215 roku, kiedy to odwrócił swe polityczne sojusze przeciw Cesarstwu Łacińskiemu. Raptem to kilka miesięcy. Ale nadzieje na łacińską koronę, jeśli się ona w ogóle marzyła węgierskiemu monarsze, tym samym stawały się nierealne po lecie 1215 roku. Czy w takiej sytuacji Andrzej II, zerwawszy w 1215 roku sojusz z Henrykiem, mógł przejąć Cesarstwo Łacińskie w roku 1216? Taka hipoteza wydaje się być niezasadna.

Po wyłonieniu elekta na tron w Konstantynopolu przez radę baronów, posłańcy łacińscy: Eustachy z Hainaut, Jan z Brabancji i Robert z Boves - latem lub jesienią 1216 roku - wyruszyli do Namur, gdzie rezydował Piotr z Courtenay. ${ }^{20}$ Choć brak dowodów na ten fakt, w drodze na dwór elekta Piotra, posłańcy mogli odwiedzić króla Andrzeja II i jego małżonkę. Jeżeli tak istotnie było, to posłańcy, co najwyżej, mieli do przekazania Jolancie Flandryjskiej wiadomości o śmierci wuja Henryka oraz tego, że udają się na dwór jej ojca i przyszłego cesarza łacińskiego. I zdaje się więcej kompetencji nie posiadali.

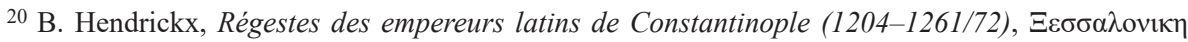
1988, nr 138, s. 96-97. 
A czy Andrzej II był skłonny wikłać się w zaistnienie w Konstantynopolu po roku 1215? Wydaje się to wątpliwe w tej konfiguracji politycznej. Przeciw temu zaświadczały: nadal zła sytuacja wewnętrzna na Węgrzech, niedobre stosunki z Wenecjanami, którzy byli najpoważniejszą siłą w Cesarstwie Łacińskim, choć nie zamierzali brać odpowiedzialności politycznej za sprawowanie rządów, a jedynie strzec własnych praw i interesów rękoma swoich podestów. Andrzej II, choć nie mógł mieć nadziei by zostać łacińskim cesarzem, to jednak podjął decyzję o opuszczeniu Węgier w 1217 roku. Tu dotykamy być może sedna sprawy. Akces krzyżowca zgłaszał on trzykrotnie - w latach 1201, 1209 i 1213. Innocenty III był jednak temu przeciwny z racji fermentu na Węgrzech. ${ }^{21}$ Zapał i przede wszystkim możliwości sfinansowania krucjaty przez węgierskiego krzyżowca tłumiły wcześniej wydarzenia wewnętrzne: walki z bratem, bunty, chaos, potem śmierć królowej Gertrudy, i to one, stawały dotąd, na przeszkodzie nie pozwalając wyruszyć - już nie tak - młodemu królowi do Ziemi Świętej.

Czy apel nowego papieża ${ }^{22}$, Honoriusza III (1216-1227), był dostateczną zachętą do udania się króla do Outremer? Nie można zapominać, że funkcjonował przykład innych monarchów z XII w., którzy wyruszali na krucjaty. Andrzej II tym samym zyskiwałby poklask w sferach Kościoła węgierskiego, stawał się egzemplifikacją etosu rycerskiego, mógł się kreować na specjalnie wyróżnionego w oczach poddanych, gdyż, jako pomazaniec Boży, szedł za głosem Boga, jako wojownik za wiarę. To niewątpliwie mogło przyczynić się do wzrostu autorytetu i prestiżu arpadzkiego monarchy. Nie można po raz kolejny zapominać o kwestiach genealogicznych. Rodzicami Andrzeja II - byli Béla III i Agnieszka z Châtillon, z czworga przodków - jego dziadków - należy wyróżnić linię antenatów macierzystych. Jego babką była Konstancja z Antiochii (1127-1163), natomiast dziadkiem był regent Księstwa Antiochii, Renald z Châtillon (ok. 1125-1187). Spędził on 16 lat w niewoli muzułmańskiej i został osobiście stracony przez sułtana Saladyna po bitwie pod Hittinem 4 VII 1187 roku za swe nikczemności. Może były, więc jakieś inne, nieznane nam rodzinne sentymenty i przesłanki, skłaniające króla Andrzeja II, aby dotrzeć do Ziemi Świętej, nie zaś bardzo wątpliwie nadzieje na władzę w Cesarstwie Łacińskim?

Andrzej II udał się w lecie 1217 roku do Splitu w Dalmacji. Tam król ułożył się z Wenecjanami pomimo sprawy Zadaru (XI 1202), a 23 sierpnia, zaledwie na dwóch wynajętych splitańskich statkach pożeglował do Akki. ${ }^{23}$ W Ziemi Świętej Andrzej II nie zabawił długo, może czerpiąc wzory od Filipa Augusta. Na początku 1218 roku król zaopatrzywszy się w relikwie i rozpoczął powrót do ojczyzny. Wracał do domu drogą lądową przez Armenię, gdzie obiecał swego syna Andrzeja (ok. 1210-1234) ożenić z dwuletnią wówczas Izabellą (1216/17-1252), córką armeńskiego króla

${ }^{21}$ List Innocentego III, J. P. Migne, Patrologia latina, 216, col 757, XV, 222.

22 G. Fejér, Codex diplomaticus Hungariae ecclesiaticus ac civilis, t. III, vol. 1, Budae 1829, s. 187.

${ }^{23}$ Ex Thomae historia pontificum Salonitanorum et Spalatinorum, ed. L. de Heinemann, MGH SS, 29, s. 578; Monumenta Hungariae Historica. Diplomataria. Árpádkori új okmánytár, Codex diplomatius Arpadianus continuatus, I, 1001-1235, ed. Gusztáv Wenzel, Pest 1860, s. 29. 
Leona I. Do ślubu jednak nigdy nie doszło. Dalej Andrzej II odwiedził Nikeę i dwór Teodora Laskarysa (1204-1222). Wówczas uzgodniono zaślubiny najstarszego syna i następcy Andrzeja II, przyszłego króla Béli IV (1235-1270), z Marią (1206-1270), córką Teodora. ${ }^{24}$ Nadto Andrzej II zawarł wówczas jeszcze inny sojusz, w sprawie małżeństwa swojej córki, Anny Marii (1204-1237), która poślubiła władcę Bułgarii, Iwana-Asena (1218-1241). Przygoda Andrzeja II z piątą krucjatą zakończyła się dla niego zbliżeniem z Nikeą i osłabioną Bułgarią, nie zaś z Cesarstwem Łacińskim. Filip van Tricht sugeruje, jak B. Hóman w 1943 roku, że był to plan zawarcia sojuszy małżeńskich dla incontrovertibly the Hungarian king's imperial aspirations, które król planował zrealizować w przyszłości. Ale na podstawie, czego F. van Tricht zbudował swoją hipotezę o planach monarchy, nie wiadomo. Wreszcie, belgijski uczony doszedł do wniosku, że po śmierci cesarzowej Jolanty w wrześniu 1219 roku, nikt w Konstantynopolu nie pragnął widzieć na tronie Andrzeja II, co ostatecznie przekreślało jego nadzieje na imperialny tytuł. A czy jest jakiś dowód, że Andrzej II wcześniej widział się na tronie w Konstantynopolu? Uważam, że nikt z baronów Cesarstwa nie pragnął na tronie łacińskim Andrzeja II, ani w 1216 roku ani w 1219 roku, gdyż po prostu nie ma na to dowodów. ${ }^{25}$

Reasumując - uważam, że Andrzej II nie udał się na V krucjatę celem zdobycia władzy w Konstantynopolu. Hipotezy B. Hómana, S. Runcimana i podtrzymujących to współczesnych niektórych historyków węgierskich, nie mają umocowania źródłowego. Andrzej II, istotnie, tylko przez bardzo krótki okres, rzędu kilku miesięcy - od lutego do lata 1215 roku - mógł marzyć o zdobyciu schedy w Cesarstwie Łacińskim po Henryku, gdyby ten akurat wtedy zmarł. Ta konstrukcja myślowa stawałaby się realną, gdyby po zgonie Henryka, baronowie Cesarstwa wskazali na Andrzeja II, jako przyszłego cesarza. A nic takiego nie miało miejsca, albo o tym nic nie wiadomo. Dodatkowo, zbliżenie Andrzeja II do Stefana II Nemanicza jednoznacznie przekreśliło takie nadzieje króla już latem 1215 roku. Po śmierci cesarza Henryka, baronowie Cesarstwa, nie mogli tym samym lokować w Andrzeju II nadziej sukcesyjnych. Król Węgier miał słaby mandat, aby wejść w sprawy Cesarstwa, a podesta wenecki, z dużą dozą prawdopodobieństwa, nie poparłby kandydatury węgierskiego monarchy. Nie apetyty na Konstantynopol wpłynęły na decyzję tego króla, aby

${ }^{24}$ A. Potthast, Regesta Pontificum Romanorum, I, Graz 1957, s. 593, nr 6845 z 28 V 1222; G. Fejér, Codex diplomaticus Hungariae ecclesiaticus ac civilis, t. III, vol. 1, Budae 1829, s. 384; Vetera Monumenta historica Hungariam sacram illustrantia, I, ed. Augustino Theiner, 33, nr 67; Chronica Albrici monachii Trium Fontium a monacho novi monasterii Hojensis interpolata, ed. Paul Scheffer-Boichorst, MGH SS 23, s. 911; Ex Thomae historia pontificum Salonitanorum et Spalatinorum, ed. L. de Heinemann, MGH SS, 29, s. 579; W. Felczak, Historia Węgier, Wrocław-Warszawa-Kraków-Gdańsk-Łódź 1983, s. 41 stwierdził, że Andrzej II liczył na osiągnięcie tronu w Konstantynopolu po nieudanej wyprawie do Ziemi Świętej. Jeszcze inaczej widział to S. A. Sroka, Historia Węgier..., s. 41 pisząc, iż Andrzej II myślał o zdobyciu tronu w Konstantynopolu i dlatego przygotowywał się na V krucjatę.

${ }^{25}$ F. Van Tricht, The Latin Renovatio..., s. 417n.; Van Tricht poszedł tropem B. Hómana, zob. B. Hóman, Geschichte..., s. 14-21, upatrując w planowanych mariażach dzieci Andrzeja II, „okrążenie” Cesarstwa Łacińskiego; zob. G. Kristó, Az aranybullák évszázada, Budapest, 1976, s. 50 - „wyprawa turystyczna"; G. Kristó, A Kárpát medence és a Magyarság régmúltja (1301-ig), Szeged 1994, s. 232. 
wyruszyć do Outremer. Opowiadam się za wskazaniem, jako głównych impulsów decyzyjnych w podjęciu wyprawy do Ziemi Świętej przez Andrzeja II, wątków prestiżowych (król-krzyżowiec), dewocyjnych (kolekcjonowanie relikwii) i ambicjonalnych. Pielgrzymka króla do Ziemi Świętej wpisywała się praktykę monarchów europejskich i być może wcześniejszych aspiracji Andrzeja II, aby krucjacie przewodził arpadzki król.

\section{BIBLIOGRAFIA}

Acropolites Georgii, Opera recensuit Augustus Heisenberg, editionem anni MCMIII, correctiorem curavit Peter Wirth, vol. I, Stutgardiae 1978, B. G. Teubner.

Almási T., II. András, w: Noémi Gujdár, Nóra Szatmáry, Magyar királyok nagykönyve. Uralkodóink, kormányzóink és az erdélyi fejedmek életének és tetteinek képes töténete, Budapest 2012, s. 85-87, Reader's Digest.

Chronica Albrici monachii Trium Fontium a monacho novi monasterii Hojensis interpolata, ed. Paul Scheffer-Boichorst, MGH SS 23, Leipzig 1925, Verlag P. Hiersemann.

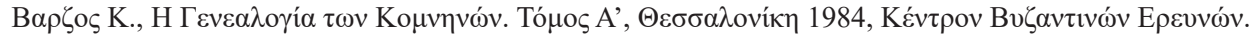

Божилов И., Фамилята на Асеневцฺи (1186-1460). Генеалогия и просопография, София 1985, Издателство БАН.

Browning R., A new source in Byzantine-Hungarian relations in the twelfth century, Balkan Studies" 2

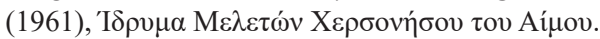

Dokumenty soborów powszechnych, tekst grecki, taciński, polski, tom II (869-1312). Konstantynopol IV, Lateran I, Lateran II, Lateran III, Lateran IV, Lyon I, Lyon II, Vienne, układ i opracowanie ks. Arkadiusz Baron, ks. Henryk Pietras SJ, Kraków 2002, Wydawnictwo WAM.

Chronica de Gestis Hungarorum ab origine gentis ad a. 1330, ed. Dezső Dercsény, New Tork 1970, Corvina, Taplinger Publishing.

Codex dipomaticus Regni Croatiae, Dalmatiae et Slavoniae, collegit et digessit T. Smičiklas, Zagrebiae 1904, Edidit Academia Scientiarum et Artium Slavorum Meridonalium auxilio Regiminis Croatiae, Dalmatiae et Slavoniae.

Czamańska I., Aspekty ruchu krucjatowego na Wegrzech w XI-XV wieku, w: Rycerstwo Europy środkowoWschodniej wobec idei krucjat. Redakcja naukowa Wojciech Peltz, Jarosław Dudek, Zielona Góra 2002, s. 131-138, Wydawnictwo Uniwersytetu Zielonogórskiego.

Dölger F., Regesten der Kaiserkunden des oströmischen Reiches von 565-1453, Bd. II, 1455, München 1959, Verlag C. H. Beck.

Ex Thomae historia pontificum Salonitanorum et Spalatinorum, ed. L. de Heinemann, MGH SS 29, Leipzig 1925, Verlag P. Hiersemann.

Fejér G., Codex diplomaticus Hungariae ecclesiasticus ac civilis. Tomus III. Vol. 1 (Budae, 1829), Typis Typogr. Regiae Vniversitatis Vngaricae.

Felczak W., Historia Węgier, Wrocław-Warszawa-Kraków-Gdańsk-Łódź 1983, Wydawnictwo Zakładu Narodowego im. Ossolińskich.

Grousset R., Historie des croisades et du Royaume Frans de Jérusalem, t. 3, Paris 1936, Perrin

Hauziński J., Imperator "końca świata” (1194-1250), Gdańsk 2000, s. 45-46, Wydawnictwo „Marpress”.

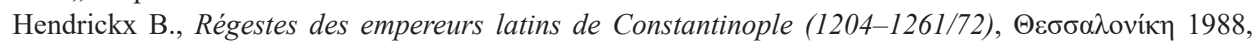

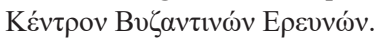

Hóman B., Geschichte des ungarischen Mittelalters, 2. Band: Vom Ende des 12. Jahrhuderts bis zu den Anfängen des Hauses Anjou, Übersetzung Hildegard von Roosz und Max Pfotenhauer, Berlin 1943, Verlag Walter De Gruyter \& Co. 
Јиречек К., Историја Срба, t. 1, Београд 1952; Научна Книга, Издавачко Предузеће Народне Републике Србије.

Ioannis Cinnami, Epitome, rerum ab Ioanne et Alexio Comnenis gestarum, ed. Augustus Meineke, Bonnae 1836, Impresis Weberi.

Kristó G., Az aranybullák évszázada, Budapest, 1976, Gondolat.

Kristó G., A Kárpát-medence és a Magyarság régmúltja (1301-ig), Szeged 1993, Szegedi Középkorász Mühely.

Kristó G., Makk F., Az Árpád-ház uralkodói, Budapest 1996, I. P. C. Könyvek.

Longnon J., L'Empire Latin de Constantinople et la Principauté de Morée, Paris 1949, Payot.

Magdalino P., The Empire of Manuel I Komnens 1143-1180, Cambridge 1993 Cambridge University Press.

Makk F., The Árpáds and the Comneni: Political relations between Hungary and Byzantium in the 12 the century, trans. by György Novák, Budapest 1989, Akadémiai Kiadó.

Migne J. P., Patrologia latina, 216, Sirou.

Monumenta Hungariae Historica. Diplomataria. Árpádkori új okmánytár, Codex diplomatius Arpadianus continuatus, I, 1001-1235, ed. Gusztáv Wenzel, Pest 1860, Magyar Tudományos Akademia.

G. Moravcsik, Byzantium and the Magyars, Budapest-Amsterdam 1970, Akadémiai Kiadó.

G. Moravcsik, Pour une alliance byzantino-hongroise, „Byzantinische Zeitschrift” 33, Leipzig 1933, B. G. Teubner.

Ostrogorsky G., Dzieje Bizancjum. Przekład pod redakcją H. Evert-Kappesowej, Warszawa 1969, Państwowy Instytut Wydawniczy.

Ostrogorsky G., Urum-Despotes. Die Anfänge der Despotenwürde in Byzanz, „Byzantinische Zeitschrift” 44, München 1951, Ch. Beck'sche Verlagsbuchhandlung.

Památky dřevního písmenictví Jihoslavanův, sebral a vydal Pavel Josef Šafařík, Praha 1873, B. Tempsky.

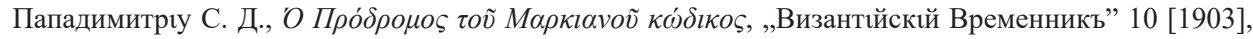
Императорская Академเя Наукъ.

Pentek Z., Cesarstwo Lacińskie 1204-1261. Kolonialne państwo krzyżowców czy Neobizancjum? Poznań 2004, Wydawnictwo Poznańskie.

Potthast A., Regesta Pontificum Romanorum, I, Graz 1957, Akademische Druck u. Verlagsangstalt

Röhricht R., Quinti Belli sacri scriptores minores, Genf 1879, Typis F.-G. Fick.

Röhricht R., Studien zur Geschichte des fünften Kreuzzuges, Innsbruck 1891, Verlag der Wagner'schen Universitäts-Buchhandlung.

Röhricht R., Testimonia minora de quinto bello sacro e chronicis occidentalibus, Genf 1882, Typis F.-G. Fick.

Runciman S., A History of the Crusades, t. III, Cambridge 1954, Cambridge University Press.

Runciman S., Dzieje wypraw krzyżowych, t. 3, thum. Jerzy Schwakopf, Warszawa 1987, Państwowy Instytut Wydawniczy.

Sišić F., Poviest Hrvata za kraljeva iz doma Arpadovića, Zagreb 1944, Matica hrvatska.

Sroka S. A., Historia Wegier do 1526 roku w zarysie, Bydgoszcz 2000, Homini.

Stephenson P., Byzantium's Balkan Frontier. A political study of the Northern Balkans, 900-1204, Cambridge 2000, Cambridge University Press.

Stiernon L., Notes de titulature et de prosopographiè, „Revue des Études Byzantines” 23(1), Institut Française d'Études Byzantines.

The history of the crusades, ed. by Kenneth M. Setton, vol. II, Madison, Milwuakee, London 1969, The University of Wisconsis Press.

Urkunden zur älteren Handels- und Staatsgeschichte der Republik Venedig mit besonderer Beziehung auf Byzanz und die Levante, ed. G. L. Fr. Tafel, G. M. Thomas, Wien 1856, w: Fontes rerum Austriacarum, Österreichische Geschichts-Quellen, hrsg. von der Historischen Commission der Kaiserlichen Akademie der Wissenschaften in Wien. Zweite Abteilung: Diplomataria et acta, Bde. II, Der Kaiserlich-Königlichen Hof- und Staatsdruckerei. 
Успенский Фиодор И., История Византийской Империи, Москва-Ленинград 1948, Издательство Академии Наук СССР.

Van Tricht F., The Latin Renovatio of Byzantium. The Empire of Constantinople (1204-1228), translated by Peter Longbottom, Leiden-Boston 2011, Brill.

Vetera Monumenta historica Hungariam sacram illustrantia, I, ed. Augustino Theiner, Romae 1859, Apud editorem.

Wasilewski T., Stefan Nemanjić, w: Stownik Starożytności Stowiańskich, Wrocław-Warszawa-KrakówGdańsk 1975, Wydawnictwo Zakładu Narodowego im. Ossolińskich.

Wolski J. M., „Żywot św. Sawy” Teodozjusza Chilandarskiego, jako źródto do dziejów Streza, władcy Proseku, „Balcanica Posnaniensia. Acta et studia” XIX [2012], Instytut Historii UAM. 
